\title{
Pancreatic islet allograft in spleen with immunossuppression with cyclosporine. Experimental model in $\operatorname{dog} \mathbf{s}^{1}$
}

\author{
Alotransplante de ilhotas pancreáticas no baço com imunossupressão com ciclosporina. Modelo \\ experimental em cães
}

\begin{abstract}
Jaques Waisberg ${ }^{\mathrm{I}}$, Charles Benjamin Neff ${ }^{\mathrm{II}}$, Daniel Reis Waisberg ${ }^{\mathrm{III}}$, Demetrius Germini ${ }^{\mathrm{IV}}$, José Eduardo Gonçalves ${ }^{\mathrm{V}}$, Arnaldo Zanotto $^{\mathrm{VI}}$, Manlio Basilio Speranzini ${ }^{\mathrm{VII}}$

IPhD, Associate Professor, Department of Surgery, Faculty of Medicine of ABC, Santo Andre-SP, Brazil. Responsible for intellectual and scientific content of the study, responsible for manuscript writing, supervised all phases of the study, designed the protocol, involved with technical procedures.

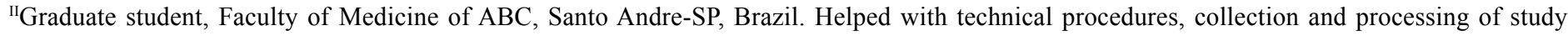
informations, responsible for English language.

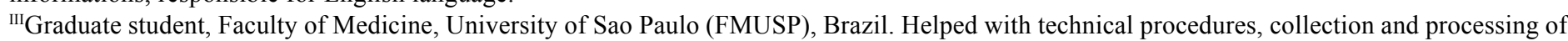
study informations.

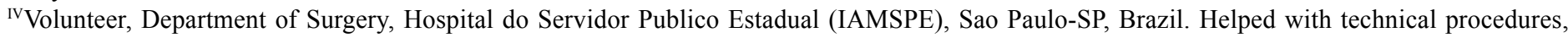
collection and processing of study informations.

${ }^{\mathrm{v}} \mathrm{PhD}$, Department of Surgery, IAMSPE, Sao Paulo-SP, Brazil. Designed the protocol, involved with technical procedures, acquisition and interpretation of data.

${ }^{\mathrm{VI}}$ Assistant Professor, FMUSP, Sao Paulo-SP, Brazil. Statistical analysis.

${ }^{\mathrm{VII}} \mathrm{PhD}$, Full Professor, Department of Surgery, Faculty of Medicine of ABC, Santo Andre-SP, Brazil. Critical revision.
\end{abstract}

\begin{abstract}
PURPOSE: To study the functional behavior of the allograft with immunosuppression of pancreatic islets in the spleen.

METHODS: Five groups of 10 Mongrel dogs were used: Group A (control) underwent biochemical tests; Group B underwent total pancreatectomy; Group C underwent total pancreatectomy and pancreatic islet autotransplant in the spleen; Group D underwent pancreatic islet allograft in the spleen without immunosuppressive therapy; Group E underwent pancreatic islet allograft in the spleen and immunosuppression with cyclosporine. All of the animals with grafts received pancreatic islets prepared by the mechanical-enzymatic method - stationary collagenase digestion and purification with dextran discontinuous density gradient, implanted in the spleen.

RESULTS: The animals with autotransplant and those with allografts with immunosuppression that became normoglycemic showed altered results of intravenous tolerance glucose $(\mathrm{p}<0.001)$ and peripheral and splenic vein plasmatic insulin levels were significantly lower $(\mathrm{p}<0.001)$ in animals that had allografts with immunosuppression than in those with just autotransplants.

CONCLUSIONS: In the animals with immunosupression with cyclosporine subjected to allograft of pancreatic islets prepared with the mechanical-enzymatic preparation method (stationary collagenase digestion and purification with dextran discontinuous density gradient), the production of insulin is decreased and the response to intravenous glucose is altered.
\end{abstract}

Key words: Islets of Langerhans Transplantation. Diabetes Mellitus, Experimental. Animal Experimentation. Dogs.

\section{RESUMO}

OBJETIVO: Avaliar o comportamento funcional do alotransplante com imunossupressão de ilhotas pancreáticas no baço.

MÉTODOS: Foram utilizados cinco grupos de 10 cães mestiços: grupo A (controle) submetido aos exames bioquímicos; grupo B, submetido à pancreatectomia total; grupo $\mathrm{C}$ (autotransplante) submetido à pancreatectomia total e autotransplantação de ilhotas pancreáticas no baço; grupo D, submetido à alotransplantação de ilhotas pancreáticas no baço sem terapia imunossupressiva; grupo E, submetido à alotransplantação de ilhotas no baço e imunossupressão com ciclosporina. Todos os animais transplantados receberam ilhotas pancreáticas isoladas pelo método mecânico-enzimático, digestão estacionária com colagenase e purificação com gradiente de densidade descontínua de dextran e foram implantadas no baço.

RESULTADOS: Animais autotransplantados e alotransplantados com imunossupressão que se tornaram normoglicêmicos apresentaram testes de tolerância à glicose intravenosa alterados $(\mathrm{p}<0,001)$ e o nível de insulina plasmática periférica e na veia esplênica foram significantemente menores $(\mathrm{p}<0,001)$ nos animais alotransplantados com imunossupressão em relação aos autotransplantados.

CONCLUSÃO: Nos animais submetidos ao alotransplante de ilhotas pancreáticas com imunossupressão com ciclosporina e preparadas pelo método mecânico-enzimático, digestão estacionária com colagenase e purificação com gradiente de densidade descontínua de dextran, a produção de insulina está diminuída e a resposta à sobrecarga de glicose intravenosa alterada.

Descritores: Transplante das Ilhotas Pancreáticas. Diabetes Mellitus Experimental. Experimentação Animal. Cães. 


\section{Introduction}

Diabetes mellitus is the major cause of neuropathy, amputation and impotence in the Western hemisphere and is one of the main chronic debilitating childhood diseases ${ }^{1}$. It is estimated that $4 \%$ of the worldwide adult population is a carrier of diabetes mellitus, $10 \%$ of them with type 1 or juvenile diabetes ${ }^{1}$

Even with satisfactory results, pancreatic transplant is an involved operation, not without potentially serious complications ${ }^{1}$. In this sense, the transplant of pancreatic islets is an attractive alternative as it is a minor procedure without the risk of potentially serious complications observed with total pancreatic transplants ${ }^{1,2}$. Pancreatic islet transplantation has been intensively studied as an alternative to vascularized transplant of the pancreas ${ }^{3,4}$.

The disadvantages of pancreatic islet transplant are the difficulty of isolating viable and functioning human islets in sufficient quantities to maintain a normoglycemic state, and the immunogenocide of the islets that requires considerable amounts of immunosuppressive drugs to prevent rejection ${ }^{5}$.

However, the more compact pancreas of large mammals yields a low number of functionally viable and isolated pancreatic islets caused by the strong connections between their own islets and the pancreatic exocrine tissue that surrounds them ${ }^{6-9}$.

For the clinical transplantation of pancreatic islets to be enhanced, it is imperative that certain conditions must be assured. First, it is necessary to create a large mammal model in which the problems of the isolation of islets are similar to the conditions of the human pancreas. Second, the islet transplants should have extended follow-up to study their accommodation to the site of ectopic implantation. Third, the response to food intake should be studied, because it is an accurate indicator of the metabolic control achieved with the insulin supplementation caused by to the pancreatic islet transplantation ${ }^{1}$.

Therefore, the search for experimental models of isolation and transplantation involving efficiency and simplification of the procedures remains an objective to be pursued so that the clinical transplant of pancreatic islets can become a safe and efficient therapeutic option 5 .

The purpose of this study was to evaluate the functional behavior of the allograft with immunosuppression with cyclosporine of pancreatic islets isolated using the method of mechanical-enzymatic preparation (stationary collagenase digestion and with dextran discontinuous density gradient) in the spleen of dogs.

\section{Methods}

Fifty young adult male mongrel dogs were used and they weighed between $8 \mathrm{~kg}$ and $12 \mathrm{~kg}$. The use of laboratory animals follows the Council for International Organization of Medical Sciences (CIOMS) ethical code for animal experimentation ${ }^{10}$.

The animals were divided into 5 groups, each consisting of 10 dogs. In the control group (A), the animals were not operated on and demonstrated normal fasting glucose values, fasting insulin and intravenous glucose tolerance tests (IGTT). In the other groups, all the animals underwent total pancreatectomy without duodenectomy ${ }^{11}$. In group B, the animals underwent only a total pancreatectomy; in group $\mathrm{C}$, the animals also underwent the autotransplant of pancreatic islet tissue in the spleen; in group D, the animals were submitted to allograft of pancreatic islet tissue in the spleen without immunosuppression, and in group E, the allograft of pancreatic islet tissue in the spleen was done with immunosuppression.

All the animals operated on had laparotomy performed through a ventral midline incision. The main pancreatic duct was immediately isolated before its penetration of the duodenal wall. The preparation of the pancreatic tissue, the pancreatectomy, and the pancreatic islet isolation procedures were performed as previously described ${ }^{9,12}$. The degree of contamination was measured by comparison relative to the quantity of stained islets and of the stained acinar and non-acinar tissue (Figure 1).

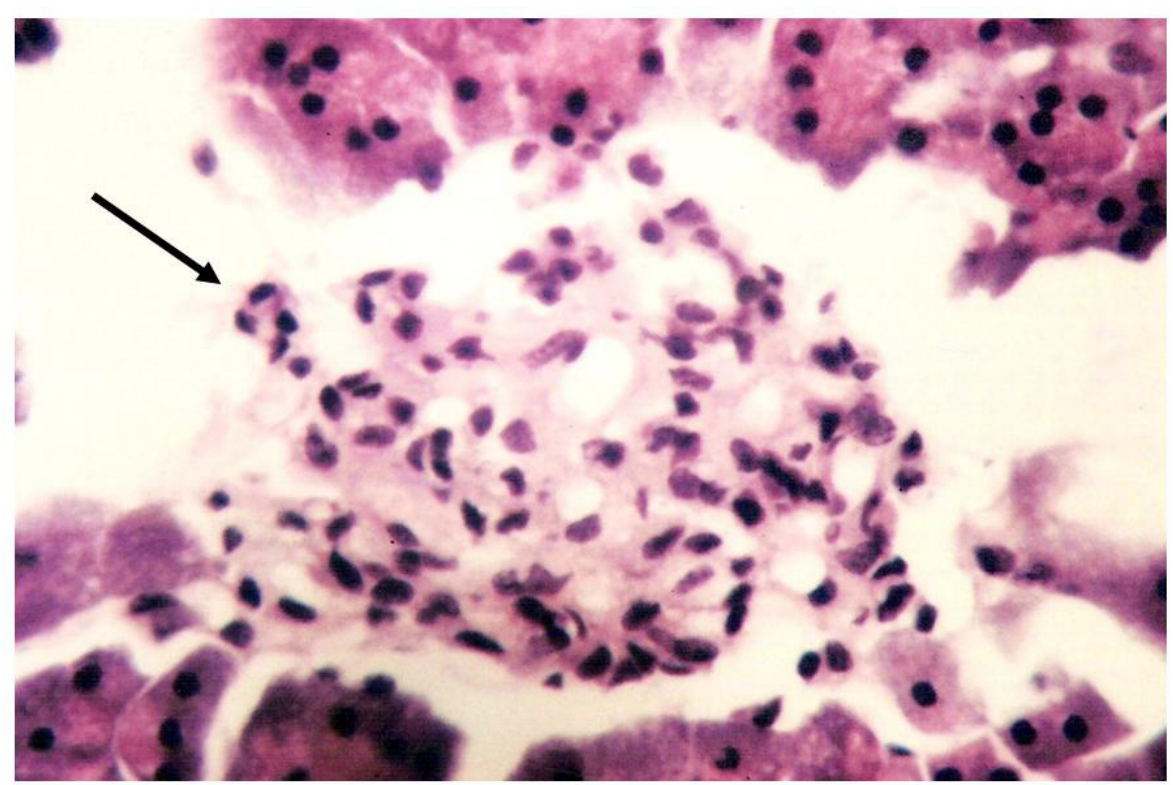

FIGURE 1 - Photomicrograph of pancreatic islet (arrow) separated from the surrounding exocrine tissue, after pancreatic tissue preparation (Hematoxilin and Eosine; X400). 
The animals in groups $\mathrm{C}, \mathrm{D}$, and $\mathrm{E}$ were kept under general anesthesia, while the pancreas was subjected to procedures for isolation and purification of pancreatic islet tissue. Upon completion of these procedures, 3 to 4 tributary veins of the splenic vein were isolated in the region near the splenic hilum. The veins were partially opened from their anterior surface and catheterized toward the spleen with a polyvinyl tube of diameter 4 Fr. Temporary obstruction of the splenic pedicle vessels was performed using bulldog-type vascular clamps, and maintained for $5 \mathrm{~min}$ after finishing the infusion of the pancreatic islet preparation. The islet preparation was injected through the intravenous catheters by retrograde infusion using a similar amount for each one. After removal of the occlusive clamps from the splenic pedicle, repair of the peritoneal cavity was performed and then it was washed with warm saline.

The animals in group E received intramuscular injections of cyclosporine in an intramuscular dose of $20 \mathrm{mg} / \mathrm{kg} /$ day the evening before transplantation. In the post-transplant period, the animals received intramuscular injections of cyclosporine is a dose of 10 to $20 \mathrm{mg} / \mathrm{kg} /$ day adjusted to maintain average blood levels of $300 \mathrm{ng} / \mathrm{mL}$. The plasma levels of cyclosporine were determined twice a week by radioimmunoassay. In all the animals of this group, the cyclosporine was discontinued on the 30th day after transplant. The method employed to determine serum cyclosporine was the Incstar cyclo trac spserum/plasma RIA (INCSTAR Corporation, Stillwater, Minnesota, USA).

The insulin level was determined by radioimmunoassay using antibody anti-insulin (DSL-1600 Insulin Radioimmunoassay Kit). The result was expressed in $\mu \mathrm{UI} / \mathrm{mL}$. In the animals of group B (apancreatic), the blood samples for the insulin dosage were collected during fasting immediately pre-operation and on the 7 th day post-pancreatectomy. In the animals of group $\mathrm{D}$, the insulin level was determined on the 14 th day post operation. The insulin dosages of the animals in groups $\mathrm{C}$ and $\mathrm{E}$ were collected pre-operation, on the 14th and 28th day post-transplant during the performance of the splenectomy in the animals that survived until then. The collected blood was centrifuged at $3000 \mathrm{rpm}$ and the plasma obtained was stored in a freezer at $-25^{\circ} \mathrm{C}$.

All the animals had their fasting glucose levels determined with reagent strips and instrument readings by a spectrophotometer glucometer (Glucometer II). In the animals of group A, the fasting glucose was determined only once and served to obtain the normal values. The animals in groups $\mathrm{B}$ and $\mathrm{D}$ had their glucose determined before the operation and every 3 days. For the animals in groups $\mathrm{C}$ and $\mathrm{E}$, the fasting glucose was determined in the preoperative period and every 3 days after the graft, and after the splenectomy the determination was done daily. The glucose results were expressed in milligrams\% $\%(\mathrm{mg} \%)$. Fasting normoglycemia was defined up to a value of $150 \mathrm{mg} \%$. Functional failure of the pancreatic islet graft was considered as a fasting glucose level greater than $200 \mathrm{mg} \%$ for at least 2 consecutive days after the 14 th day post-transplant.
In the IGTT, glucose in the form of $50 \%$ dextrose and at a dose of $0.5 \mathrm{~g} / \mathrm{kg}$ ( $\mathrm{kg}$ of body weight) was injected through the catheter placed in the radial vein, and blood samples were withdrawn through the catheter in the femoral vein at $0,10,20$, $30,60,90$ and $120 \mathrm{~min}$. In the animals of group B, the test was performed on the 7th day post-pancreatectomy and the animals in groups C, D and E were also subjected to IGTT on the 14th day post-transplant.

The animals remained fasting in the immediate postoperative period and, from the first day post-operation, were progressively fed with water, a milk diet, and a standard diet ad libitum. All the animals operated on received a pancreatic enzyme concentrate. The animals in groups $\mathrm{B}, \mathrm{C}, \mathrm{D}$, and $\mathrm{E}$ received intramuscular cefoxitine $(40 \mathrm{mg} / \mathrm{kg}$ ) during the first $24 \mathrm{~h}$.

The surviving animals from groups $\mathrm{C}$ and $\mathrm{E}$ were operated on again at 28 days post-transplant. The vena cava below the level of the renal veins and the splenic vein next to the spleen were punctured to obtain blood samples for the determination of insulin level. Next, the splenectomy was performed.

The following statistical tests were applied: analysis of variance for repeated measures, the Tukey and de Newman-Keuls multiple comparison test, Student $t$ test, paired $t$ test and analysis of variance (ANOVA). In all the tests, a significance level of 5\% $(p \leq 0.05)$ was adopted. The statistical program used was SPSS 14.0 for Windows.

\section{Results}

The mean fasting glucose levels of the animals in the different groups are listed in Table 1. There was no significant difference $(p=0.9)$ between the mean fasting glucose values for the animals in group $\mathrm{A}$ and the mean pre-operation fasting glucose values of the animals in groups $\mathrm{B}, \mathrm{C}, \mathrm{D}$, and $\mathrm{E}$ (Table 1).

In the animals from group B, the fasting glucose levels reached every 3 days starting the first post-operative day showed that all the animals became hyperglycemic with blood glucose levels above $150 \mathrm{mg} \%$, and remained hyperglycemic until death (Table 1). In the animals from group $\mathrm{C}$, the fasting glucose levels showed that all the dogs remained hyperglycemic until at least the 7 th day after the autotransplant. The glucose levels from the 10th day after autotransplant showed that 6 animals achieved normoglycemia while the other 4 remained hyperglycemic; from the 13th day after, allograft from these hyperglycemic animals became normoglycemic (Table 1) and remained so until the 28 th day after autotransplant. The postsplenectomy blood glucose levels in this group of animals showed hyperglycemic levels in all, and remained this way until death. All of the animals in this group died between the 12th and 17 th day post-splenectomy.

In the animals from group D, the fasting glucose levels showed hyperglycemia in all, a situation that continued until death (Table 1). The mean levels of fasting blood glucose of 
the animals from this group remained at hyperglycemic levels from the first post-operative day until death on the 15 th day after transplant of the last surviving animal.

In the animals from group E, the fasting glucose levels showed hyperglycemia in all the animals until the 10th day after allograft (Table 1). Starting at day 13, 7 dogs achieved normoglycemia and remained this way until day 25 post-allograft. On the 28th day after allograft, the determination of the fasting blood glucose level showed that 2 animals became hyperglycemic, whereas other 2 other animals that behaved hyperglycemic since the first day after allograft showed fasting normoglycemia. After having the splenectomy on the 30th day post-allograft, all of the animals from this group showed hyperglycemia beginning on the first day and remained hyperglycemic until the death of the last surviving animal. All of the splenectomized animals died between the 9 th and 14th day after splenectomy.

TABLE 1 - Values of the means and respective standard deviations of the fasting glucose levels (mg\%) pre-operative and post-operative in the animals of groups B (apancreatic), C (autotransplant), D (allograft without immunosuppression) and E (allograft with immunosuppression).

\begin{tabular}{|c|c|c|c|c|c|c|c|}
\hline \multicolumn{8}{|c|}{ GLUCOSE (mg\%) } \\
\hline \multirow[t]{2}{*}{ GROUPS } & & $\begin{array}{c}\text { PRE- } \\
\text { OPERATIVE }\end{array}$ & \multicolumn{5}{|c|}{ POST-OPERATIVE } \\
\hline & & & $1^{\circ}$ & $4^{\circ}$ & $7^{\circ}$ & $10^{\circ}$ & $13^{\circ}$ \\
\hline \multirow[t]{2}{*}{$\mathrm{B}$} & M. & 88.50 & 207.40 & 262.60 & 282.70 & 279.33 & 289.00 \\
\hline & S.D. & 15.81 & 38.38 & 40.80 & 36.56 & 25.85 & 35.04 \\
\hline \multirow[t]{2}{*}{$\mathrm{C}$} & M. & 88.50 & 224.40 & 200.00 & 176.30 & 145.70 & 123.60 \\
\hline & S.D. & 15.14 & 19.96 & 25.14 & 23.33 & 19.22 & 12.46 \\
\hline \multirow[t]{2}{*}{$\mathrm{D}$} & M. & 90.00 & 212.70 & 191.40 & 236.30 & 283.63 & 327.00 \\
\hline & S.D. & 17.66 & 27.61 & 24.82 & 38.42 & 25.18 & 17.72 \\
\hline \multirow[t]{4}{*}{$\mathrm{E}$} & M. & 88.10 & 242.70 & 215.90 & 194.80 & 173.70 & 154.40 \\
\hline & S.D. & 15.93 & 23.08 & 25.62 & 23.47 & 21.83 & 21.80 \\
\hline & ANOVA & $p=0.9$ (N.S.) & $p=0.03 *$ & $\mathrm{p}<0.001^{*}$ & $\mathrm{p}<0.001^{*}$ & $\mathrm{p}<0.001^{*}$ & $\mathrm{p}<0.001^{*}$ \\
\hline & M. $=$ Mean & S.D. $=$ Standard & lation & $=$ Not sig & icant & Significant & \\
\hline
\end{tabular}

The IGTT performed on the animals in groups B, C, D and $\mathrm{E}$ (Table 2) was altered. A significant difference $(p<0.0001)$ was observed between the determinations of $0,10,20,30,60,90$, and 120 min of the IGTT and between the animals of groups A, B, C, D, and E $(p<0.001)$ (Table 2).
The IGTT values at times $0,10,20,30,90$, and 120 minutes for the animals in group E exhibited significant differences $(p<0.05)$ when compared with the corresponding standard values of the animals from group A. There was a significant difference $(p<0.0001)$ between the mean values of fasting glucose levels at different times of the IGTT for the animals from groups A, B, C, $\mathrm{D}$, and $\mathrm{E}$ (Table 2). 
TABLE 2 - Mean values ( $\mathrm{mg} \%$ ) and the respective standard deviations of the intravenous glucose tolerance test (IGTT), performed on the animals in groups A (control), B (apancreatic), C (autotransplant), D (allograft without immunosuppression) and $\mathrm{E}$ (allograft with immunosuppression).

\begin{tabular}{|c|c|c|c|c|c|c|c|c|}
\hline \multicolumn{9}{|c|}{ TIME (MINUTES) } \\
\hline Groups & & $\mathbf{0}$ & 10 & 20 ' & 30' & 60 & 90 & $120^{\prime}$ \\
\hline \multirow[t]{2}{*}{$\mathrm{A}$} & M. & 92.00 & 203.60 & 182.80 & 159.10 & 143.40 & 118.40 & 87.20 \\
\hline & S.D. & 10.02 & 26.43 & 19.65 & 16.07 & 14.40 & 8.17 & 10.58 \\
\hline \multirow[t]{2}{*}{ B } & M. & 306.20 & 416.60 & 379.10 & 348.50 & 322.10 & 304.10 & 299.70 \\
\hline & S.D. & 43.12 & 52.64 & 45.97 & 41.06 & 37.04 & 35.08 & 46.34 \\
\hline \multirow[t]{2}{*}{$\mathrm{C}$} & M. & 106.50 & 262.50 & 235.00 & 200.20 & 157.30 & 130.90 & 99.70 \\
\hline & S.D. & 12.67 & 11.75 & 20.33 & 23.77 & 27.47 & 18.95 & 16.31 \\
\hline \multirow[t]{2}{*}{$\mathrm{D}$} & M. & 275.25 & 372.75 & 353.25 & 346.00 & 328.25 & 305.75 & $278, .5$ \\
\hline & S.D. & 30.05 & 30.51 & 23.33 & 21.49 & 27.61 & 26.55 & 30.02 \\
\hline \multirow[t]{3}{*}{$\mathrm{E}$} & M. & 157.00 & 258.70 & 257.40 & 227.80 & 200.00 & 179.70 & 142.60 \\
\hline & S.D. & 17.99 & 45.70 & 14.90 & 20.31 & 18.41 & 20.62 & 23.95 \\
\hline & ANOVA & $p<0.001^{*}$ & $p<0.001^{*}$ & $p<0.001^{*}$ & $p<0.001 *$ & $p<0.001^{*}$ & $p<0.001^{*}$ & $p<0.001 *$ \\
\hline & M. $=\mathrm{N}$ & & $*$ & nificant & & & deviation & \\
\hline
\end{tabular}

The mean values of peripheral blood insulin in the animals of group A was $11.39 \pm 1.77 \mu \mathrm{U} / \mathrm{mL}$ and in the animals from groups $\mathrm{B}, \mathrm{C}$, and E pre- and post-operation are listed in Table 3. There was no significant difference $(p=0.18)$ between the mean values of pre-operative peripheral blood insulin from animals of groups $\mathrm{B}, \mathrm{C}, \mathrm{D}$, and $\mathrm{E}$.
There was a significant difference $(p<0.001)$ between the mean values of peripheral blood insulin determined on the 14th day post-transplant in the animals from groups B, C, D, and E. The insulin levels at 14 days post-transplant in the animals from group $\mathrm{C}$ were significantly $(p<0.05)$ higher than those in group $\mathrm{E}$ (Table 3 ). The mean value of peripheral blood insulin determined on the 28th day post-transplant in the animals of group $\mathrm{C}$ was significantly $(p<0.001)$ higher than that obtained from animals in group E. 
TABLE 3 - Means $(\mu \mathrm{U} / \mathrm{mL})$ and respective standard deviations of the peripheral blood insulin levels pre-operative and post-operative in the animals of groups B (apancreatic), C (autotransplant), D (allograft without immunosuppression) and $\mathrm{E}$ (allograft with immunosuppression).

\begin{tabular}{|c|c|c|c|c|c|}
\hline \multirow{3}{*}{ GROUPS } & & \multicolumn{4}{|c|}{ INSULIN LEVEL } \\
\hline & & \multirow[t]{2}{*}{ PRE-OPERATIVE } & \multicolumn{3}{|c|}{ POST-OPERATIVE } \\
\hline & & & $7^{\circ}$ & $14^{\circ}$ & $28^{\circ}$ \\
\hline \multirow{2}{*}{$\mathrm{B}$} & M. & 11.14 & 2.75 & & \\
\hline & S.D. & 1.61 & 0.51 & & \\
\hline \multirow{2}{*}{$\mathrm{C}$} & M. & 12.50 & & 7.97 & 6.80 \\
\hline & S.D. & 2.04 & & 0.69 & 0.90 \\
\hline \multirow{2}{*}{$\mathrm{D}$} & M. & 12.71 & 4.16 & & \\
\hline & S.D. & 2.62 & 0.46 & & \\
\hline \multirow{3}{*}{$\mathrm{E}$} & M. & 11.24 & & 5.98 & 4.99 \\
\hline & S.D. & 1.45 & & 1.58 & 0.53 \\
\hline & ANOVA & $p=0.18$ (N.S.) & $\mathrm{p}<0.001 *$ & $p<0.001^{*}$ & $p<0.001 *$ \\
\hline
\end{tabular}

The mean values of blood insulin in the splenic vein on the 28th day post-transplant, collected during performance of the splenectomy on the animals of groups $\mathrm{C}$ and $\mathrm{E}$ are listed in Table 4 .

The mean value of blood insulin levels obtained in the inferior vena cava of the animals in group $\mathrm{C}$ was significantly $(p<0.001)$ higher than that of group E. The mean value of blood insulin levels obtained in the splenic vein of the animals in group $\mathrm{C}$ was significantly $(p<0.001)$ higher than in the dogs from group E (Table 4). When the mean values of the blood insulin levels obtained from the inferior vena cava and the splenic vein, respectively, of the animals in groups $\mathrm{C}$ and $\mathrm{E}$ were compared, the values obtained from the splenic vein were significantly $(p<0.001)$ higher than those from the inferior vena cava (Table 4$)$.

TABLE 4 - Mean values $(\mu \mathrm{U} / \mathrm{mL})$ and respective standard deviations of the insulin levels determined in the inferior vena cava and in the splenic vein on the 28th day post-operation in the animals of groups C (autotransplant) and E (allograft with immunosuppression).

\begin{tabular}{|c|c|c|c|}
\hline \multirow[t]{2}{*}{ GROUPS } & & \multicolumn{2}{|c|}{ INSULIN LEVELS } \\
\hline & & INFERIOR VENA CAVA & SPLENIC VEIN \\
\hline \multirow{2}{*}{$\mathrm{C}$} & M. & 7.26 & 20.69 \\
\hline & S.D. & 1.00 & 4.06 \\
\hline Paired $t$ test & & $\mathrm{p}<0.001^{*}$ & $\mathrm{p}<0.001^{*}$ \\
\hline \multirow{2}{*}{$\mathrm{E}$} & M. & 4.21 & 5.19 \\
\hline & S.D. & 0.28 & 0.37 \\
\hline Student $t$ test & & $p<0.001^{*}$ & $p<0.001 *$ \\
\hline
\end{tabular}

M. = Mean $\quad *=$ Significant $\quad$ S.D. $=$ Standard deviation




\section{Discussion}

The mechanical manipulation represented by the centrifuge and the transfer using pipettes, as well as the exposure to hyperosmolar chemical substances during the purification process of islets, can damage and fragment the islets, altering their viability and functionality at the site of ectopic transplantation ${ }^{2,5,13-}$ 15. These events may have contributed to the failure of the grafts in the animals that were subjected to auto- and allotransplantation.

All of these technical peculiarities of preparation and implementation of pancreatic islet transplantation imply the need for a greater initial volume of islets to compensate for the loss of viable islets during the many stages of the process ${ }^{5-7}$.

The inadequate mass of beta cells is considered the most frequent non-immunological cause for the failure of allogenic transplant of pancreatic islets ${ }^{5,13,14}$. Because the preparation of "purified" canine islets is estimated to yield approximately $20 \%$ of the total initial content of the intact pancreas ${ }^{3,5,15}$, it is expected that the secretion of insulin should be significantly lower in the animals subjected to pancreatic transplantation than in the control animals ${ }^{4,5}$. In this study, it was found that there was a significant reduction in the insulin levels between pre- and post-transplant in the animals of groups C, D, and E. This reduction was attributed to the reduction of the functionally active endocrine tissue mass transplanted into the spleen because of the process of pancreatic islet preparation.

We used the injection of the islet preparation by retrograde infusion in tributary vessels of the splenic vein so that the graft reached the splenic pulp. Studies show that the technique of injection of islets by direct puncture of the splenic pulp through the organ encapsulation is less efficient in comparison with the technique of venous reflux through the branches of the splenic vein $^{2,14}$, as it was used in the present experiment.

Other authors ${ }^{4,5}$ have also observed changes in the insulin serum levels. It was found that there is a reduction in the secretion of insulin by the grafted pancreatic islet cells, even when fasting normoglycemia is restored. The reduction in the islet cell mass and the absence of the enervation of the islets in the heterotopic location can directly contribute to hypo-insulinemia ${ }^{3}$. The reduction in tolerance to glucose in the animals autotransplanted with pancreatic islets is due to decreased insulin secretion response to intravenous glucose ${ }^{5}$. In pancreatic islet autotransplantation in dogs, the blood levels of insulin in the splenic vein show multiple peaks accompanied by normoglycemia during the post-prandial period $^{5,15}$

In the current study, the degree of change in the IGTT was less in the autotransplant group and progressively greater in the animals of the allograft with immunosuppression, allograft without immunosuppression, and apancreatic groups. The degree of change in IGTT showed a direct relationship with the magnitude of insulin secretion by the islet transplant that was greater in the animals with autotransplant and less in the animals from the allograft with immunosuppression group. The apancreatic animals showed low insulin levels as a function of residual pancreatic parenchyma that was not totally removed during the performance of the total pancreatectomy. Despite the incomplete removal of insulin production in the apancreatic animals, they behaved metabolically like diabetics and showed, in the post-operative period, a clinical picture of ketoacidosis, hyperglicemia, polyuria, polidipsia, and severe loss of body weight.

Other factors may contribute to modulating the immune response to islet allo-antigens. When species-specific tolerance is conferred, while when using mongrel dogs, as in the present experiment, maximum incompatibility is involved ${ }^{6,7,13}$. In addition, the maintenance of the spleen, or lack thereof, in the recipient animals can cause some difference ${ }^{4,5}$. In this experiment, the mongrel dogs used, the changes in the functionality of the pancreatic islets derived from many stages of isolation and their implantation in the spleen, and the spleen itself as the location for the reception of the pancreatic islets may have contributed to the failure to obtain normoglycemia in some of the animals from the allograft with immunosuppression group.

The metabolic performance of the allograft during IGTT remained similar to that of the control animals, despite the significant decrease in the plasma insulin response. These results are similar to the metabolic response of the islet allografts with a single donor, purified or from pancreatic microfragments transplanted in immunosuppressed $\operatorname{dog} s^{6,7,15}$. It is possible that the inhibition of insulin secretion attributed to cyclosporine can be partially circumvented by an increase in the mass of the islet cells ${ }^{7}$. However, there is a need for a minimum critical level of cyclosporine to prevent rejection of the islets $\mathrm{s}^{6,7,13,15}$.

In the present study, the production of insulin in the transplanted animals from the allograft with immunosuppression group showed no significant difference between the animals in this group, suggesting that the deleterious effect of cyclosporine on the glucopenic efficiency of insulin may have contributed, at least partially, to the failure to obtain normoglycemia in the 3 dogs.

The attempts to establish experimental models of pancreatic islet allografts in large animals is considered important and necessary, especially to improve the isolation techniques for pancreatic islets and establishing clinical research protocols in order to elucidate various aspects as yet undefined for pancreatic islets transplantation, in order to provide human recipients of these future transplants the greatest safety and efficiency possible.

\section{Conclusions}

In the animals with immunosupression with cyclosporine subjected to allograft of pancreatic islets prepared with the mechanical-enzymatic preparation method (stationary collagenase digestion and purification with dextran discontinuous density gradient), the production of insulin is decreased and the response to intravenous glucose is altered. 


\section{References}

1. Close N, Alejandro R, Hering B, Appel M. CITR Investigators. Second annual analysis of the collaborative islet transplant registry. Transplant Proc. 2007;39:179-82.

2. Waisberg J, Magalhães RR, Gonçalves JE, Landman G, Zanotto A, Speranzini MB. Aspectos funcionais do autotransplante de ilhotas de Langerhans no baço. Estudo experimental em cães. Acta Cir Bras. 1987;2:121-7.

3. Fujino Y. Two-layer cold storage method for pancreas and islet cell transplantation. World J Gastroenterol. 2010;16:3235-8.

4. Wang W, Liu S, Zheng W, Gao F, Hawthorne WJ, Yi S. Hepatic artery vs. portalvein infusion of microbeads: a large animal pre-clinical model evaluating the intrahepatic capacity for cell infusion and imaging. Xenotransplantation. 2010;17:207-14.

5. Kim SJ, Joh JW, Lee SK, Choi IS, Lee WY, Heo JS, Lee MK, Yang TY, Jeong IK, Oh SH, Kim BJ, Kim KW, Lee BB. Pancreatic islet cell autotransplantation in the canine model. Transplant Proc. 2000;32:2473-4. 6. Hefty TR, Kuhr CS, Chong KT, Guinee DG, Wang W, Reems JA, Greenbaum CJ. Omental roll-up: a technique for islet engraftment in a large animal model. J Surg Res. 2010;161:134-8.

7. Shapiro AM, Hao EG, Lakey JR, Finegood DT, Rajotte RV, Knetman NM. Defining optimal immunosuppression for islet transplantation based on reduced diabetogenicity in canine islet autografts. Transplantation. 2002;74:1522-8.
8. Waisberg J, Fonseca Filho PP, Araújo MR, Rahal AB, Gonçalves JE, Zanotto A, Speranzini MB. Isolamento das ilhotas de Langerhans pela digestão do tecido pancreático com colagenase tipo V. Estudo experimental em cães. Acta Cir Bras. 1987;2:45-50.

9. Waisberg J, Soares HP, Altieri LG, Altieri LG, Ramaciorri O, Speranzini MB. Pancreatic islet isolation by mechanical-enzymatic separation, stationary collagenase digestion and dextran discontinuous density gradient purification: experimental study in dogs. Acta Cir Bras. 2002; 17:89-94.

10. Howard-Jones N. A CIOMS ethical code for animal experimentation. WHO Chron. 1985;39:51-6.

11. Cobb LF, Merrell RC. Total pancreatectomy in dogs. J Surg Res. 1984;37:235-40.

12. Horaguchi A, Merrell RC. Preparation of viable islet cells from dogs by a new method. Diabetes. 1981;30:455-8.

13. Ito T, Omori K, Rawson J, Todorov I, Asari S, Kuroda A, Shintaku J, Itakura S, Ferreri K, Kandeel F, Mullen Y. Improvement of canine islet yield by donor pancreas infusion with a p38MAPK inhibitor. Transplantation. 2008;86:321-9.

14. Waisberg J, Gonçalves JE, Cruz RRM, Landman G, Zanotto A, Speranzini MB. Technical basis of autotransplantation of islets in the spleen. ABCD Arq Bras Cir Dig. 1989;4:14-20.

15. Stagner JI, Rilo HL, White KK. The pancreas as an islet transplantation site. Confirmation in a syngeneic rodent and canine autotransplant model. JOP. 2007;8:628-36.

\section{Correspondence:}

Jaques Waisberg

Rua das Figueiras, 550/134

09080-300 Santo André - SP Brasil

Tel.: (55 11)8256-0018

Fax: (55 11)5573-8854

jaqueswaisberg@uol.com.br

Conflict of interest: none

Financial source: none

${ }^{1}$ Research performed at Department of Surgery, Faculty of Medicine of ABC, Santo Andre-SP, Brazil.

Presented at the XII National Congress on Experimental Surgery of the Brazilian Society for Development of Research in Surgery-SOBRADPEC, 2011 October 26-29 Ribeirao Preto-SP, Brazil. 


\section{FACULDADE DE MEDICINA DO ABC}

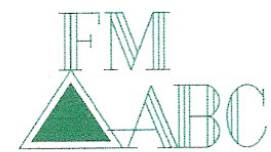

MANTIDA PELA FUNDAÇĀO DO ABC

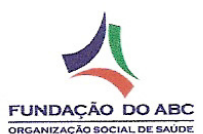

FACULDADE DE MEDICINA DO ABC

\section{DECLARAÇÃO}

Declaramos para os devidos fins que os procedimentos aplicados aos animais utilizados no estudo intitulado Auto e alo-enxerto intra-esplênico de ilhotas pancreáticas separadas pelo método mecânico-enzimático, digestão estacionária com colagenase e purificação com gradiente de densidade descontínua de dextran: estudo experimental em cães que teve como pesquisador responsável o $\mathrm{Dr}$. Jaques Waisberg, estão de acordo com os princípios éticos em experimentação animal do Colégio Brasileiro de Experimentação Animal (COBEA), filiado ao International Council for Laboratory Animal Science (ICLAS). Tanto o manejo, quanto os procedimentos experimentais propriamente ditos (incluindo pré, trans e pós-operatório), foram acompanhados pela médica veterinária responsável pelo setor de Experimentação Animal e Biotério da Faculdade de Medicina do ABC. No período de realização dos procedimentos com os animais do referido estudo, não havia sido ainda instalado o Comitê de Ética em Experimentação Animal da Faculdade de Medicina do ABC.

Santo André, 25 de junho de 2007

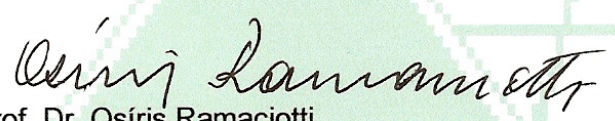

Prof. Dr. Osíris Ramaciotti

Professor Titular da Disciplina de Fundamentos da Cirurgia da Faculdade de Medicina do ABC Responsável pelo Setor de Experimentação Animal e Biotério da Faculdade de Medicina do ABC

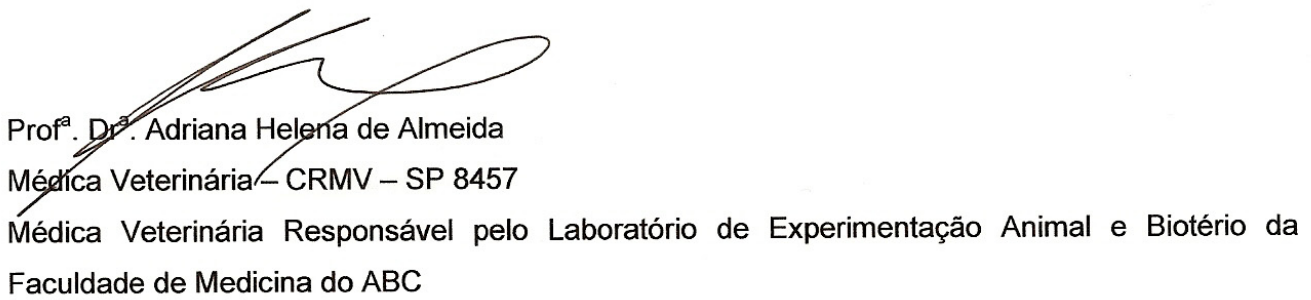

Sede: Avenida Lauro Gomes, 2000 - Sacadura Cabral - Santo André - SP - cep: 09060-870

Fone: (11) 4993-5400 - Caixa Postal 106 - e-mail: fmabc@fmabc.br 